\title{
Investors Reaction to Market Surprises on the Indian Stock Exchange and Currency Markets
}

\author{
Yaman Ö. Erzurumlu (Corresponding author) \\ Faculty of Engineering, Department of Engineering Management \\ Bahçeşehir University Beşiktaş, İstanbul, 34353, Turkey \\ E-mail: yamanomer.erzurumlu@eng.bahcesehir.edu.tr
}

Richard A. Ajayi

College of Business, Department of Finance

University of Central Florida Orlando, FL 32816-1400

E-mail: rajayi@bus.ucf.edu

Received: April 8, 2014 Accepted: May 18, $2014 \quad$ Published: June 1, 2014

doi:10.5296/ajfa.v6i1.5441 URL: http://dx.doi.org/10.5296/ajfa.v6i1.5441

\begin{abstract}
This paper examines the reaction of investors to the arrival of unexpected information on the Indian equity and foreign exchange markets. Market surprises are identified using a strictly quantitative approach, and cumulative abnormal returns are calculated and tracked for a period of 30 days after each favorable or unfavorable event.

The empirical results provide evidence that the reactions of investors following unexpected bad news on the Mumbai Stock Exchange (MSE) and the rupee-dollar exchange market are consistent with Uncertain Information Hypothesis (UIH). This means that following a major unfavorable event, security prices are initially set below their fundamental values while subsequent clarifications of the uncertainty results in positive price movements to their equilibrium levels. The results indicate that reactions on the MSE for unexpected good news are mostly positive but modestly significant while reactions on the FOREX following positive surprises are barely positive and not statistically significant. The overall results for both markets are therefore consistent with the UIH but stronger and statistically significant in the case of negative market surprises.
\end{abstract}




\section{Macrothink}

Asian Journal of Finance \& Accounting ISSN 1946-052X

A possible implication of this study for investors is that employing an investment strategy of buying losers in both markets following a sharp decline may generate superior returns.

Keywords: Market efficiency, Underreaction, Overreaction, Uncertainty, Abnormal returns JEL Classification: G14; G15 


\section{Introduction}

In the past three decades the efficient market hypothesis (EMH) has been the most venerable tenet of financial economics and a staple of academic analysis. The EMH suggests that security prices reflect all currently available public information and therefore securities are efficiently priced around their fundamental values. The hypothesis rests on the assumption that investors are rational and they, therefore, set the value of equities based on their ability to process information unambiguously. If the EMH holds, it follows that investors cannot consistently earn abnormally high returns using trading rules based on currently available information.

In recent years, however, the validity of the EMH has been challenged by behavioral financial economists. They argue that market participants include not only rational economic agents but also "behavioral economic agents" so-called "noise traders" whose asset allocation and trading decisions are often driven by irrational and sentimental considerations (Lee, Shleifer and Thaler, 1990 and 1991).In addition, some studies claim that increasing presence of these noise traders relative to institutional traders, and the concomitant risks introduced by these unsophisticated traders, result in return anomalies (Kamara,1997; Lee, Shleifer and Thaler, 1991; and Shleifer, 2000).In this framework, noise traders systematically form expectations based on erroneous interpretations of economic events thereby generating systematic risk, or noise trader risk, which is incorporated into equilibrium security prices.

Furthermore, theoretical models have been proposed in which the presence of noise traders induces rational investors to pursue unexpected favorable feedback strategies, which destabilizes security prices (De Long et.al., 1990). These considerations imply that the interaction of multiple classes of investors with heterogeneous beliefs about expected returns for assets results in less-than-optimal equilibrium prices.

In recognition of the presence of both "rational economic agents" and "behavioral economic agents" in securities markets, three alternative hypotheses have been proposed in the finance literature. DeBondt and Thaler $(1985,1987)$ advance the "overreaction hypothesis" $(\mathrm{OH})$ to explain the potential sentimental behavior of market participants and their subsequent deviation from rationality by being overly optimistic or pessimistic in response to the arrival of new information. They argue that investors overreact to unexpected information by setting security prices too high in reaction to good news, and too low in reaction to bad news. Larson and Madura (2001) document a similar pattern for the exchange market. The second competing explanation, the "uncertain information hypothesis" (UIH) set forth by Brown, Harlow and Tinic (1988), postulates that investors are not necessarily irrational, but they respond to increased uncertainty caused by unexpected arrival of new information. They, therefore, initially set security prices below their fundamental values. Subsequent clarifications of the uncertainty result in price reversion to equilibrium levels over time. We speculate that the prediction of the UIH is consistent with rational investors' reaction to "noise-trader risk," which is priced in equilibrium as an additional risk factor. Securities exposed to such a risk will consequently be underpriced following the arrival of good or bad news. The third competing explanation, the "underreaction hypothesis" (UH), predicts that 
security prices will move in the same direction of the initial price change as new information is slowly incorporated into prices and investors revise their initial estimates in the same direction. The literature presents a vast amount of evidence in support of underreaction hypothesis. ${ }^{1}$

Appendix I provides a graphical illustration of the stock market reaction to unexpected information under the four competing hypotheses outlined above. Panel A displays instantaneous price adjustments to the unexpected arrival of favorable or unfavorable news as proposed by the EMH. Panel B shows a pattern of price reversals following an initial overreaction to good or bad news as posited by the $\mathrm{OH}$. Panel $\mathrm{C}$ displays price adjustments consistent with the predictions of the UIH, whereby price adjustments are positive, or at least non-negative, following the arrival of unexpected information. Panel D displays price adjustments consistent with the prediction of $\mathrm{UH}$, where initial price adjustments are followed by revisions in the same direction.

The objective of this paper is to examine investors' reactions to surprises on the Mumbai Stock Exchange and rupee/dollar exchange market. Specifically, we examine daily returns from the Mumbai Stock Exchange and identify51major unexpected events (identified using a strictly quantitative trigger-point approach).We also examine daily changes in the foreign exchange market and identify 33 major unexpected events during the period of January 1987 to July 2012to investigate whether investors' reactions are consistent with the predictions of the efficient market hypothesis $(\mathrm{EMH})$, the overreaction hypothesis $(\mathrm{OU})$, the uncertain information hypothesis (UIH) or the underreaction hypothesis (UH).

Empirical results from this study indicate a significant increase in the volatility of daily returns following the arrival of unexpected news in both markets during the sample period. Furthermore, the findings suggest that increases in volatility of returns following major market surprises (good or bad)are associated with increases in returns in the stock markets, a result consistent with the prediction of the uncertain information hypothesis (UIH).In the same vein, reactions to unfavorable events in the foreign exchange market (depreciation of rupee) are also followed by significant positive changes(appreciation of the rupee), a result consistent with the uncertain information hypothesis (UIH) but the pattern of the investor's reaction to favorable surprises on the currency market is weakly positive and not statistically significant. Therefore, we believe that the empirical evidence presented here supports the notion that the presence of "noise trader risk" in the Indian stock market leads rational investors to respond to new information (good or bad)according to the predictions of the uncertain information hypothesis. However, the empirical evidence regarding rupee-dollar currency market is consistent with the uncertain information hypothesis and statistically significant only in the case of negative surprises.

\footnotetext{
${ }^{1}$ Jegadeesh and Titman (1993), Ikenberry, Lakonishok, and Vermaelen (1995), Michaely, Womack, and Thaler (1995), and Chan, Jegadeesh, and Lakonishok (1996), Benou (2003)
} 


\section{Macrothink}

The rest of the paper is set forth as follows. Section II presents the data and methodology. The empirical results are presented in Section III and Section IV provides the summary and concluding remarks.

\section{Data and Methodology}

\subsection{Data}

The data for this study consist of daily closing values for Mumbai Stock Exchange Index adjusted for dividends and stock splits and the rupee / dollar exchange rate from 1987 to 2012.

\subsection{Methodology}

Daily changes for MSE index and rupee-dollar exchange ratesare calculated as follows:

$$
R_{t}=\log \left(\frac{I_{t}}{I_{t-1}}\right) * 100
$$

Where, $\mathrm{R}_{\mathrm{t}}$ is the daily percentage changes of stock index or exchange rate on day $t$, and $\mathrm{I}_{t}, \mathrm{I}_{\mathrm{t}-1}$ are the closing values of stock index or exchange rate on days $t$ and $t-1$ respectively. Augmented Dickey-Fuller unit root tests (not reported here) are performed for daily changes in each index, and rejected the null hypothesis of a unit root at the $1 \%$ level of significance. Therefore, daily stock market returns and changes in exchange rates calculated in Equation (1) are stationary. Summary statistics of daily changes for the stock index and exchange rates are presented in Table 1.

Table 1. Summary Statistics for Daily Changes in the Indexes

\begin{tabular}{|l|c|c|c|c|c|c|}
\hline INDEX & DAYS & MEAN & MEDIAN & STD DEV. & MAX & MIN \\
\hline MSE & 6655 & $0.0325 \%$ & $0.0321 \%$ & $1.79 \%$ & $16.48 \%$ & $-13.45 \%$ \\
\hline FX RATE & 6595 & $0.022 \%$ & $0 \%$ & $0.43 \%$ & $12.81 \%$ & $-3.17 \%$ \\
\hline
\end{tabular}

Sample period is from January 021987 toJuly 112012

\subsection{Measuring Post-Event Variance}

To identify market surprises we use a strictly quantitative "trigger-point" approach". Appropriate number of autoregressive lags necessary in each equation to eliminate any serial correlation in the residuals is determined based on the Akaike and Schwartz values after necessary test are applied. Specifically, we estimate $\operatorname{GARCH}(1,1)$ equations for daily returns in the stock index and GARCH $(1,3)$ equation for changes in rupee-dollar exchange rates and obtained the residuals. We calculate standardized residuals (which can be interpreted as standard deviation units), and use standardized residuals that are different from the mean standardized residuals at 1\% (2.576 standard deviations) significance level to determine major event days for both series. That is, we identify the greatest positive and negative 
outliers in the standardized residuals for the market index of 6655 daily returns and for 6595 daily changes in exchange rates during the sample period. ${ }^{2}$

In the process, we identified 31major unexpected favorable events (or good news), and 20major unexpected unfavorable events (or bad news)for the stock index. For the exchange market we identified 10 unexpected favorable events (or good news) and 23 unexpected unfavorable events (or bad news). The larger number of good events over the sample space supports the argument of Bekaert etal. (2005) who notes that real economic growth was unleashed by financial liberalizations and this could be the driving force behind the data. We then track returns during a window of 30 days after each event, resulting in 1530 post-event daily returns for the stock index and 990 post-event daily changes for the exchange market. In order to prevent overlapping 30 days post-event windows, we limited the number of events to those that have no other candidate event during the post-event window. This conservative approach could only lead to lower cumulative abnormal returns rather than finding a spurious significance on the post-event cumulative abnormal returns. Table 2 displays the positive and negative trigger points used to determine favorable and unfavorable event days for the two markets, along with the number of events (good and bad) for each market. For both series the days are determined as those which standardized residuals are 2.576 (critical value for $1 \%$ ) of the standard deviation of the residuals.

Table 2. Trigger Points Used to Determine the Events for Each Market

\begin{tabular}{|l|l|l|}
\hline \multirow{2}{*}{ Market } & \multicolumn{2}{c|}{ Value of Standardized Residuals } \\
\cline { 2 - 3 } & Good News & Bad News \\
\hline MSE Index & $4.61 \%$ & $4.61 \%$ \\
\hline No of Events & 31 & 20 \\
\hline & & \\
\hline Forex & $1.12 \%$ & $1.12 \%$ \\
\hline No of Events & 23 & 10 \\
\hline
\end{tabular}

We next investigate whether the arrival of news (favorable or unfavorable) affects the volatility of stock market returns and changes in exchange rates. To do this the variance of all 30-day post-event window periods (for all favorable and unfavorable events) and the variance of non-event days (entire sample period excluding the post-event days) are compared to ascertain whether the volatility of "post-event" days and "non-event" days are equal using a difference-of-variance test. We also conduct a series of difference-of-variance tests to determine whether there is any significant difference between a) post-favorable event volatility and non-event volatility, b) post-unfavorable event volatility and non-event volatility and c) post-favorable event volatility versus post-unfavorable event volatility. 


\subsection{The Effect of Surprises on Stock Returns}

In order to investigate whether investors' response to unexpected surprises on the two markets are consistent with the predictions of the $\mathrm{EMH}, \mathrm{OH}, \mathrm{UH}$ or UIH we follow a procedure outlined in Brown et al. (1988), Ajayi and Mehdian (1994) and Ajayi et al. (2006). More specifically, we calculate daily post-event abnormal returns for both series and average them cross-sectionally for each day over the 30-day period following each set of favorable or unfavorable events in each series. Finally these 30-day abnormal returns are added together to generate cumulative abnormal returns (CARs) for each class (favorable and unfavorable) of event. Stated formally, the abnormal return for series $i$ on day $t\left(\mathrm{AR}_{\mathrm{itd}}\right)$ for $t=1$ to 30 , following an unexpected event $d$, is computed as follows:

$$
A R_{i t d}=R_{i t d}-\overline{R_{i, n o n}}
$$

Where,

$d=1 \ldots \mathrm{n}$, and $\mathrm{n}$ is the number of favorable or unfavorable events in index $i$.

$R_{i t d}=$ Return of series $i$ on day $t$ for event $d$,

$\overline{R_{i, \text { non }}}=$ Mean return of series $i$ for non-event days

The $A R_{\text {itd }}$ therefore measures the difference between changes in each series on each of the 30 days following an event and the mean change in the series non-event days.

We then calculate the mean abnormal return $\overline{A R_{i t}}$ of $n$ events for index $i$ on day $t$ as follows:

$$
\overline{A R_{i t}}=(1 / n)\left(\sum_{d=1}^{n} A R_{i t d}\right), \quad t=+1 \ldots . .+30
$$

Finally, the CARs are generated by summing up the mean abnormal returns over 30 days as:

$$
C A R_{i t}=C A R_{i(t-1)}+\overline{A R}_{i t},=\sum \overline{A R}_{i t} \mathrm{t}=1 \ldots 30
$$

We perform a standard t-test as to whether the calculated CARs are statistically different from zero. The t-statistic is stated as:

$$
t_{C A R\left(T_{1}, T_{n}\right)}=\frac{\overline{\operatorname{CAR}\left(T_{1}, T_{n}\right)}}{\left(\sigma_{\operatorname{CAR}\left(T_{1}, T_{n}\right)} / \sqrt{n}\right)} \sim n(0,30)
$$

where $T_{1}$ is day 1 and $T_{n}$ is the last day where $n$ takes values between 1 and 30 .

To assess the statistical significance of the CARs, we perform t-tests of the null hypothesis that the CARs are equal to zero during post-event windows. In addition, graphical 
representations of CARs over the 30 day window for each class of event in each series are used to determine whether investors' behavior is consistent with $\mathrm{EMH}, \mathrm{OH}, \mathrm{UIH}$, or UH.

\section{Empirical Results}

Table 3 displays daily mean returns for non-event days, all post-event days, post-favorable event days, and post-unfavorable event days, along with the sample size for each series. As can be seen, the results show that a) post-event mean returns are higher than non-event mean returns for the stock exchange and the currency market, and b) mean returns for unfavorable post-event days are higher than mean returns for favorable post-event days for both series.

Table 3. Mean Returns for Non-Event Days and Post-Event Days

\begin{tabular}{|l|l|l|l|l|}
\hline \multicolumn{1}{|c|}{ Market } & \multicolumn{1}{|c|}{$\begin{array}{c}\text { Non-Event } \\
\text { Days }\end{array}$} & $\begin{array}{c}\text { All Post } \\
\text { Event Days }\end{array}$ & $\begin{array}{c}\text { Post } \\
\text { Favorable } \\
\text { Event Days }\end{array}$ & $\begin{array}{c}\text { Post } \\
\text { Unfavorable } \\
\text { Event Days }\end{array}$ \\
\hline MSE Index & $0.019 \%$ & $0.141 \%$ & $0.129 \%$ & $0.147 \%$ \\
\hline No of days & 4894 & 1530 & 930 & 600 \\
\hline & & & & \\
\hline Forex & $-0.013 \%$ & $0.009 \%$ & $-0.008 \%$ & $0.017 \%$ \\
\hline No of days & 5098 & 990 & 300 & 690 \\
\hline
\end{tabular}

Table 4 presents the variance of daily returns for non-event days, all post-event days, favorable post-event days and unfavorable post-event days, along with the sample size for each series.

Table 4. Variance of Returns for Non-Event Days and Post-Event Days

\begin{tabular}{|c|c|c|c|c|c|}
\hline Market & Sample & Days & Variance & F-statistic(a) & F-statistic(b) \\
\hline \multicolumn{6}{|c|}{ 1. Mumbai Stock Index } \\
\hline & Non-event Days & 4894 & 2.066 & --- & \multirow[t]{2}{*}{---} \\
\hline & Post-event Days & 1530 & 2.713 & $1.131 * * *$ & \\
\hline & Favorable & 930 & 2.632 & $1.278 * * *$ & \multirow[t]{2}{*}{1.119} \\
\hline & Unfavorable & 600 & 2.940 & $1.431 * * *$ & \\
\hline \multicolumn{6}{|c|}{ 2. Exchange Rate } \\
\hline & Non-event Days & 5098 & .0710 & --- & \multirow[t]{2}{*}{---} \\
\hline & Post-event Days & 990 & .1550 & $2.183 * * *$ & \\
\hline & Favorable & 690 & .1586 & $2.233 * * *$ & \multirow[t]{2}{*}{1.079} \\
\hline & Unfavorable & 300 & .1469 & $2.069 * * *$ & \\
\hline
\end{tabular}

a) The first F-statistic(a) for stock index or exchange rate is the test statistic of the null hypothesis that the variance of post-event returns is equal to the variance of non-event returns. The second F-statistic(a) is the test statistic of the null hypothesis that the variance of returns after unexpected favorable events is equal to the 
variance of non-event returns. The third F-statistic(a) is the test statistic of the null hypothesis that the variance of returns after unexpected unfavorable events is equal to the variance of non-event returns.

b) F-statistic(b) is the test statistic of the null hypothesis that the variance of returns after unexpected favorable events is equal to the variance of returns after unexpected unfavorable events.

Note: Post-event periods contain the days after both favorable and unfavorable events.***,** and * indicates statistical significance at the $1 \%, 5 \%$ and $10 \%$ level respectively.

The F-statistics indicate that the variance of returns following favorable and unfavorable market surprises is statistically significantly higher than the variance of returns for non-event days. These results provide support for the notion that the volatility of market returns increases significantly following unexpected events. The variance column shows that post-event market volatility is higher following unfavorable events than favorable events $(2.940>2.632)$ for the MSE and higher for the favorable events $(0.1586>0.1469)$ for the exchange market but the difference exhibited is not statistically significant in both markets. This finding for the variance of MSE, is consistent with previous findings (see for example Ajayi and Mehdian, 1994) that post-event market volatility is significantly higher in the periods following unfavorable events compared to the volatility following favorable events.

Table 5. Post-Event Cumulative Average Abnormal Returns

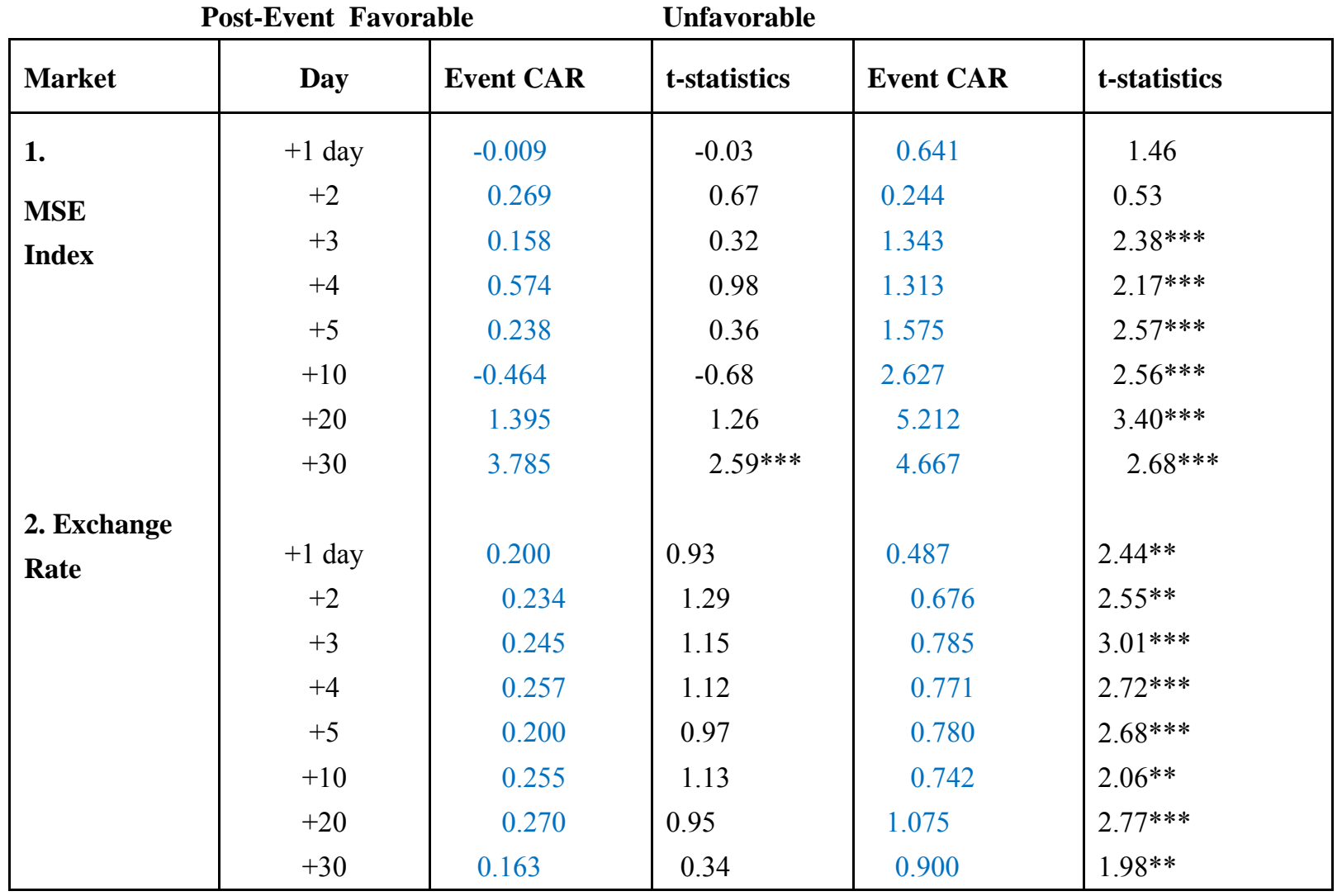

Table 5 displays post-event cumulative abnormal returns (CARs) along with their corresponding t-values for $1,2,3,4,5,10,20$, and 30 days following surprises, while Figure 2 presents the graphs of the CARs over the 30-day post-event windows for each index. The 


\section{Macrothink}

Asian Journal of Finance \& Accounting

ISSN 1946-052X

2014, Vol. 6, No. 1

$\mathrm{t}$-values are calculated using equation 5 to test the null hypothesis that the average cumulative abnormal returns (CARs) are equal to zero.
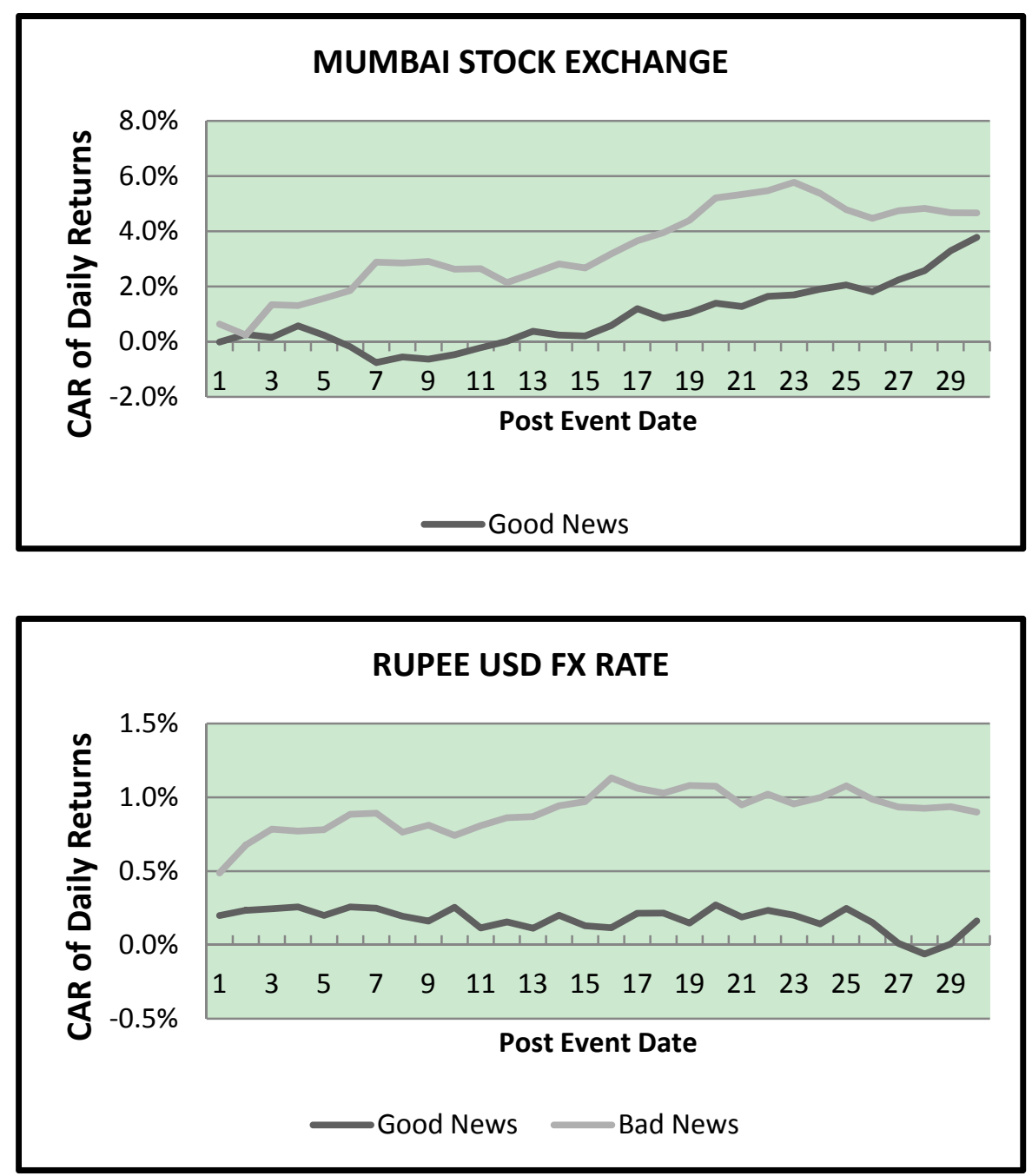

Figure1. Post-Event CARs

It is striking to note that the CARs in Table 5 and the graphs in Figure 1 exhibit a set of identifiable patterns. The CARs of Mumbai Stock Exchange exhibit largely statistically significant increases during the 30 day period following the arrival of an unfavorable market surprise. The corresponding CARs for the exchange rates exhibit the same pattern of increases though in a less dramatic fashion. The pattern exhibited by the MSE and exchange rate are consistent with the notion that the arrival of unexpected negative information generates market-wide uncertainty, inducing a pessimistic reaction on the part of investors, so that they initially set security prices below their fundamental values. However, further clarification of the uncertainty results in positive price adjustment to their fundamental values as predicted both by the UIH and $\mathrm{OH}$.

In the case of good news (favorable events),CARs for the MSE index exhibit the same pattern of increases as for bad news but in a less dramatic fashion and the increases do not attain 
statistical significance but consistent with Mazouz etal. (2009) and still fairly consistent with the UIH. The CARs for the exchange rate indicate very mild and non-statistically significant appreciation of rupee during the 30 day window following positive surprises. The overall result of rupee/ dollar exchange market can be regarded as fairly consistent with the predictions of the UIH.

Therefore, the empirical results presented here provide strong support for the predictions of the UIH for both good and bad news in the case of both MSE index and the pattern in the currency market consistent with Schnusenberg and Madura (2001) and Ajayi etal. (2006)'s studies for US market, but statistically significant only in the case of bad news. These findings, in general, reveal that the reactions of investors following unexpected news (good or bad) on both markets are characterized by subsequent price-reversals for bad news. The results confirm the findings of Lasfer etal. (2003) that negative shocks have a more pronounced effect in emerging market indexes than those of developed markets.

\section{Summary and Conclusion}

This paper examines investors' reaction following the arrival of unexpected information in the Mumbai Stock Exchange and the rupee/dollar exchange market from 1987 to 2012. Market surprises are identified for the two markets using a strictly quantitative "trigger-point" approach, and cumulative abnormal returns are calculated and traced for a period of 30 days following each favorable and unfavorable event.

The empirical results indicate a significant increase in the volatility of daily changes in the series following the arrival of unexpected news in the MSE and the foreign exchange market during the sample period. In addition, cumulative abnormal returns indicate positive changes in value following good or bad news on the stock market consistent with the UIH. However, results for the foreign exchange market indicate that positive and significant price changes are evident following unfavorable events while price changes are barely positive and not statistically significant following arrival of positive surprises.

Our overall findings are consistent with the notion that the presence of "noise trader risk" in stock market leads rational investors to respond to new unfavorable information by initially setting security prices below their fundamental values. Further clarifications of the uncertainty result in positive changes as security prices move to their fundamental values.

A possible implication of this study for investors is that implementing a semi-contrarian investment strategy of taking a long position following sharp decrease may generate abnormal results on both markets.

\section{Endnotes}

1. This approach identifies market-wide unexpected major events and does not attempt to identify any company-specific, news-specific or particular event-specific surprises. 
2. To account for the potential leverage effect of negative returns on stock market volatility, we also estimated asymmetric GARCH models for each index. The results indicate that the structure and number of outliers is not sensitive to the underlying GARCH model employed.

\section{References}

Ajayi, Richard, and Seyed Mehdian (1994) Rational Investors Reaction to Uncertainty: Evidence from the World's Major Markets. Journal of Business Finance and Accounting,s 21, 533-545. http://dx.doi.org/10.1111/j.1468-5957.1994. tb00334.x

Ajayi, Richard, Seyed Mehdian, and Mark J. Perry (2006) A test of US equity market reaction to surprises in an era of high trading volume, Applied Financial Economics, 16, 461-469 DOI: 10.1080/09603100500400510

Bekaert, Geert, Campbell R. Harvey, Christian Lundblad (2005) Does Financial Liberalization Spur Growth?. Journal of Financial Economics, 77, 3-55 http://dx.doi.org/10.1016/j.jfineco.2004.05.007

Benou, Georgina (2003). Market Underreaction to Large Stock Price Declines: The case of ADRs. Journal of Behavioral Finance, 4, No 1, 21-32. DOI: 10.1207/S15427579JPFM0401_04

Brown, Keith D., W.V. Harlow and S. M. Tinic (1988). Risk Aversion, Uncertain Information, and Market Efficiency. Journal of Financial Economics 22, 355-385. http://dx.doi.org/10.1016/0304-405X(88)90075-X

Chan, Louis K.C., Narasimham J. and Lakonishok J. (1996) Momentum Strategies. Journal of Finance, 51, 1681-1712. http://dx.doi.org/10.1111/j.1540-6261.1996.tb05222.x

De Bondt, Werner F., and Richard H. Thaler, (1985). Does the Stock Market Overreact?. Journal of Finance, 40, 793-805. http://dx.doi.org/10.1111/j.1540-6261.1985.tb05004.x

De Bondt, Werner F., \& R.H. Thaler, (1987). Further Evidence on Investor Overreaction and Stock Market Seasonality. Journal of Finance, 42, 557-581. http://dx.doi.org/10.1111/j.1540-6261.1987.tb04569.x

Delong, J. Bradford, Shleifer A., Summers L. H. \& Waldmann R. J. (1990). Unexpected Favorable Feedback Investment Strategies and Destabilizing Rational Speculation. Journal of Finance, 45, 379-395.

Ikenberry, D., Lakonishok J., \& Theo Vermaelen (1995). Market Underreaction to Open Market Share Repurchases. Journal of Financial Economics, 39, 181-208. http://dx.doi.org/10.1016/0304-405X(95)00826-Z

Jegadeesh, N., Titman S. (1993). Returns to Buying Winners and Selling Losers: Implications for Stock Market Efficiency.Journal of Finance, 48, 65-91. 10.1111/j.1540-6261.1993.tb04702.x

Kamara, A., (1997). New Evidence on the Monday Seasonal in Stock Returns. Journal of Business, 70, 63-84. 
Larson, S. J. \& Madura J. (2001). Overreaction and Underreaction in the Foreign Exchange Market.

Global

Finance

Journal

12 ,

$153-170$

http://dx.doi.org/10.1016/S1044-0283(01)00026-6

Lasfer, M., Melnik A. \& ThomasD. C. (2003). Short Term Reaction of Stock Markets in Stressful Circumstances. Journal of Banking and Finance, 27, 1959-1977. http://dx.doi.org/10.1016/S03784266(02)00313-8

Lee, C. M.C., Shleifer A. \& Thaler R.H. (1990). Anomalies: Closed-End Mutual Funds", Journal of Economic Perspectives, 4, 153-64.

Lee, C. M.C., Shleifer A. \& Thaler R.H. (1991). Investor Sentiment and the Closed-End Fund Puzzle, Journal of Finance, 46, http://dx.doi.org/10.1111/j.1540-6261.1991.tb03746.x

Mazouz, K., Nathan L. J., \& Palliere C. (2009), Stock Index Reaction to Large Price Changes: Evidence from Major Asian Stock Indexes, Pacific-Basin Finance Journal, 17, 444-459 http://dx.doi.org/10.1016/j.pacfin. 2008.11.001

Michaely,R., Womack K. \& Thaler R. (1995). Price Reaction to Dividend Omissions: Overreaction or Drift?. Journal of Finance, 50, 573-608. http://dx.doi.org/10.1111/j.1540-6261.1995.tb04796.x

MacKinlay, A. C. (1997), Event Studies in Economics and Finance. Journal of Economic Literature, 35/1, 13-39.

Ng, L. \& Wu F. (2005), Revealed Stock Preferences of Individual Investors: Evidence From Chinese Equity Markets, Pacific Basin Finance Journal, 14/2, 175-192 http://dx.doi.org/10.1016/j.pacfin.2005.10.001

Ruback, R.S. (1982). The Effect of Discretionary Price Control Decisions on Equity Values. Journal of Financial Economics, 10 83-105. http://dx.doi.org/10.1016/0304-405X(82)90031-9

Schnusenberg, O. \& Madura J. (2001). Do US Stock Market Indexes Over or Underreact?, Journal of Financial Research, 24, 179-204

Shleifer, A. (2000). Inefficient Markets: An Introduction to Behavioral Finance, London: Oxford University Press. 
Appendix I. Market Reaction to Unexpected Good and Bad News

\section{Panel A: EMH}

Good News

Bad News

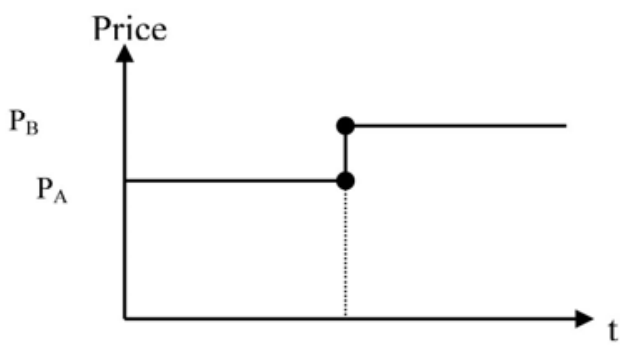

$t_{0}$

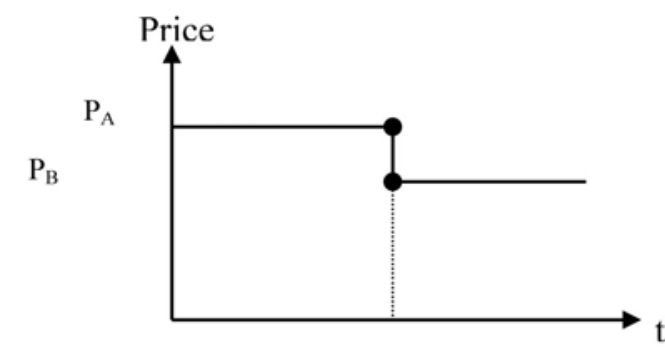

$t_{o}$

$\mathrm{P}_{\mathrm{A}}=$ price before une news

$\mathrm{P}_{\mathrm{B}}=$ price after the news

Panel B: OH
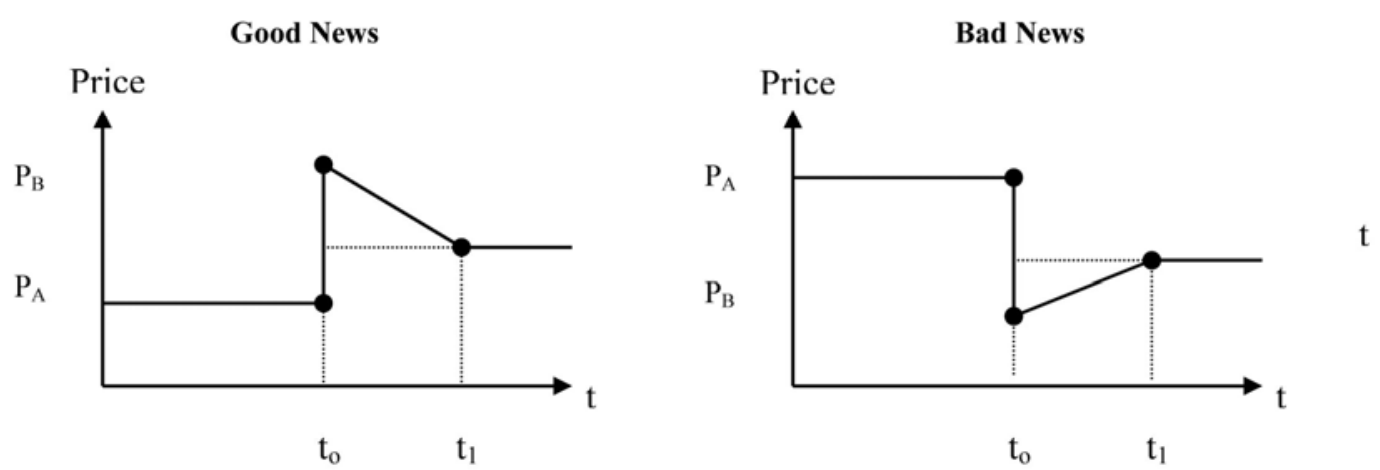

$\mathrm{P}_{\mathrm{A}}=$ price before the news

$\mathrm{P}_{\mathrm{B}}=$ price after the news 
Panel C: UIH
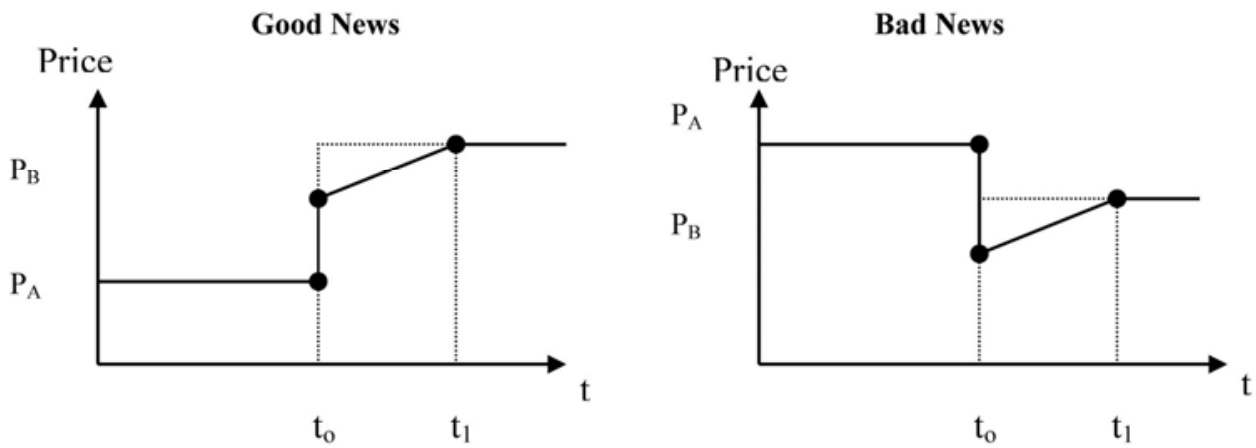

$\mathrm{P}_{\mathrm{A}}=$ price before the news

$\mathrm{P}_{\mathrm{B}}=$ price after the news

Panel D: UH

Good News

Price

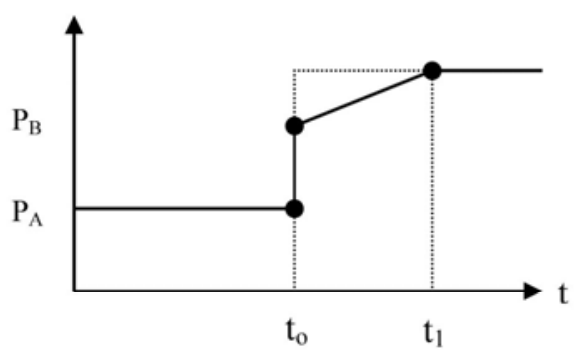

$\mathrm{P}_{\mathrm{A}}=$ price before the news

$\mathrm{P}_{\mathrm{B}}=$ price after the news
Bad News

Price

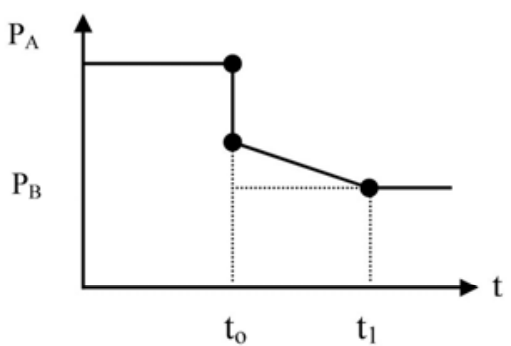

